\title{
Quantitative assessment of passenger flows in Europe and its implications for tracing contacts of infectious passengers
}

M Askar (askarm@rki.de) ${ }^{1}, 0$ Mohr ${ }^{1}$, T Eckmanns ${ }^{1}$, G Krause ${ }^{1}$, G Poggensee ${ }^{1}$

1. Robert Koch Institute, Department of Infectious Disease Epidemiology, Surveillance Unit, Berlin, Germany

Citation style for this article:

Askar M, Mohr O, Eckmanns T, Krause G, Poggensee G. Quantitative assessment of passenger flows in Europe and its implications for tracing contacts of infectious passengers. Euro Surveill. 2012;17(24):pii=20195. Available online: http://www.eurosurveillance.org/ViewArticle.aspx?Articleld=20195

Article submitted on 03 August 2011 / published on 14 June 2012

In contrast to air travel, there are no recommendations on tracing ground transport passengers exposed to infectious pathogens. We analysed European statistics on passenger transport in different conveyances and conducted expert workshops to discuss environmental conditions in ground transport, indications and minimal datasets required for contact tracing. Transport performance in the 27 countries of the European Union increased from $5.3 \times 10^{12}$ passenger kilometres $(\mathrm{pkm})$ in 1995 to $6.5 \times 10^{12} \mathrm{pkm}$ in 2007 . Each resident generated on average $13,092 \mathrm{pkm}$ in 2007 , of which 2,062 pkm were public ground transport and 1,155 pkm in air transport. In the same year in Germany the total passenger volume in all different conveyances was 67,937 million. Public ground transport accounted for a passenger volume of 11,387 million $(16.8 \%)$ and air transport for 129 million (0.2\%). High efficiency particulate air (HEPA) filtration is frequently used in airplanes but not in ground transport vehicles. Therefore opportunities for disease transmission in public ground transport are not necessarily lower than in air travel. However, contact tracing is rarely conducted in these settings because of immense logistic challenges. Indication for contact tracing should be revisited, including all kinds of passenger transport.

\section{Introduction}

A variety of infectious diseases have the potential to spread from one person to the other without the need for direct or intimate contact. In stationary settings such as workplace, school or hospital, persons potentially exposed to a patient shedding an infectious pathogen usually remain within the reach of one local health authority which can trace these contacts to initiate early diagnosis, preventive treatment or hygienic measures to prevent further spread. Travelling in public transport, often in confined spaces, provides opportunities for exposure to and transmission of infectious diseases. It is an established procedure in infectious disease control to trace passengers, with the aim of preventing further spread of a pathogen or providing post exposure prophylaxis or treatment to passengers who had contact on board a vehicle to a fellow passenger or personnel shedding an infectious agent, in the following referred to as contact tracing (CT). CT in public transport settings poses special challenges: exposed passengers usually have a one-time exposure; they do not necessarily live within one health department's jurisdiction and are unlikely to receive information on the exposure other than by direct contact from either the travel company or the health authority since most passenger ground transport vehicles do not use passenger name lists. Announcements via media or other information channels (e.g. social networks) are only rarely used to trace contacts. In public transport conveyances such as airplanes, risk assessment based on documentation of a seating position can facilitate a more focused contact tracing approach.

CT is explicitly addressed in Article 23 of the International Health Regulations from 2005 [1] and has recently led to an amendment of the Decision 2000/57/ EC of the European Commission addressing the information exchange between Member States during CT and providing and indicative list of personal data for CT [2]. In both regulations, CT is treated as a control measure which justifies and requires the maintenance of international surveillance and information exchange systems when there is a risk for international disease spread. So far official recommendations from public health institutions and the World Health Organization (WHO) do address CT in air transport, but not explicitly in public ground transport [3-13].

In our work we describe factors that may indicate the need for recommendations in the ground transport setting and try to identify to what extent these might differ from the factors known for air travel. We analysed European statistics on passenger transport in different types of conveyances. Furthermore we report results from an expert workshop that assessed indicators for $\mathrm{CT}$ in ground transport conveyances.

\section{Methods}

Public ground transport is defined as travelling by the following means of transport: bus/coach, railway or 
tram/metro. Public transport in general furthermore includes air and sea transport. Within the framework of the European project 'Response to Emerging infectious diseases: Assessment and development of Core capacities and Tools' (REACT) we conducted two meetings with international experts to identify relevant criteria and indications for $\mathrm{CT}$ in public ground transport and a generic minimal dataset for CT [14]. A survey and round table discussions determined infectious diseases pertinent to CT. Moreover, relevant environmental conditions and results of the passenger transport data analysis were discussed. Participants of the meetings were experts working in or for local and national public health departments, the International Association of Public Transport (UITP), and the WHO.

\section{European passenger transport}

Eurostat and the European Commission Directorate General for Energy and Transport provided the latest summarised European passenger transport statistics from 1995 to $2007[1,15]$. Each EU Member State reports statistical data on passenger transport in the form of passenger transport performance (TP), which is defined as the number of passengers multiplied by travelled distance and measured in passenger-kilometres (pkm). TP is reported based on the territoriality principle, i.e. only the TP within the territory of the reporting country is considered. We analysed TP for different types of transport within the 27 European Union Member States (EU-27) specifically for transport by passenger car, powered two-wheeler, bus/coach, railway, tram/metro, air, and sea transport.

\section{German passenger transport}

As the core research group was located in Germany, we used the data from Germany for the detailed analysis and comparison. We received statistical data on total number of passengers, TP, short- and long-distance travel by bus/coach and railway, and information on the average travel distance in the period 2004 to 2007 from the German federal statistical office (DESTATIS) and from the German Institute for Economic Research (DIW) [16-19].

In Germany, passenger transport by bus/coach and tram/metro is reported as public road transport. Short distance traffic by bus is defined as travel on public suburban and metropolitan commuter transport with the majority of passengers travelling less than $50 \mathrm{~km}$ or for less than one hour. Accordingly, in long-distance bus travel, the majority of passengers is travelling more than $50 \mathrm{~km}$, or for more than one hour.

Regarding transport by railway, the definition of shortversus long-distance travelling depends not only on the distance travelled (limited up to $50 \mathrm{~km}$ or more than $50 \mathrm{~km}$ ), but in some cases also on the type of conveyance. For instance, travel by high speed trains is always reported as long-distance transport, even when the travelled distance might be less than $50 \mathrm{~km} \mathrm{[18].}$
Environmental conditions in ground transport conveyances

In order to gather information on environmental conditions that may influence the risk of disease transmission in public ground transport, we conducted a literature research on technical systems such as air conditioning and ventilation used in buses/coaches and trains.

In January and February 2009, we conducted a scientific literature search on technical systems in relation to airborne transmission of infectious diseases in public ground transport using the SCOPUS database (the largest scientific database currently available). The search was conducted using a combination of keywords from three groups that were connected by 'AND'. The first group contained the following keywords: air condition, air filter, seating distance, and ventilation. The second group contained: transmission, infectious, airborne, droplet, disease, and the third group contained: means of transport, conveyance, bus, coach, railway and train. In July 2011, the literature search was updated. The search results were screened for relevance with regard to transmission of airborne infectious disease in public ground transport by two REACT researchers.

Furthermore, we contacted by email and telephone (national and Europe-wide) coach and railway transport companies and organisations as well as two internationally operating rail equipment manufacturing companies and a university research group focusing on airflows in confined spaces, in order to gather information on technical systems used in different means of transport in Europe. In addition, environmental conditions potentially relevant for CT were discussed in the REACT expert meetings.

\section{Indications for CT in public ground transport} In the REACT expert meetings we discussed pathogens and indications that could be relevant for risk assessment and decision making for CT in public ground transport, as well as the logistical challenges of conducting CT in various means of transport.

\section{Minimal dataset for CT}

The passenger locator card is a paper form available on board of aircrafts. It provides a method to rapidly collect passenger contact information and is recommended to be used when public health authorities suspect the potential for disease transmission on board of an aircraft and a subsequent need for contact tracing. It was developed by an informal transport working group convened by WHO [12]. The group consisted of representatives from national public health authorities and international transport organisations.

Annex III of Decision 2000/57/EC includes an indicative list of personal data to be collected and shared between EU Member State authorities for the purpose of CT. This list mirrors to a large extent the information to be filled in the 2009 WHO passenger locator form 
[12] and includes the passenger's name, sex, date of birth, telephone numbers, email and home addresses as well as temporary addresses (called contact information in Annex III) and emergency contact details. In addition to the passenger locator form, Annex III also contains questions on nationality, type of identity document (ID), ID number and issuing authority.

We compared the 2009 draft version of the passenger locator card [12] with the 'indicative list of personal data for the purpose of contact tracing' in Annex III of the 2009 amendment of the $2000 / 57 / E C$ Decision of the European Commission [2]. A minimal dataset required for CT was also part of the discussion at the REACT expert meetings.

\section{Results}

\section{European passenger transport}

Within the EU-27, passenger transport performance (TP) increased from $5.3 \times 10^{12} \mathrm{pkm}$ in 1995 to $6.5 \times 10^{12} \mathrm{pkm}$ ) in 2007. On average each habitant of the EU-27 generated about 13,092 pkm in 2007. Public ground transport (bus/coach, railway, and tram/metro) accounted for an average TP per EU-27 habitant of 2,062 pkm and air transport for $1,155 \mathrm{pkm}$. TP by air transport had a growth rate of $4.5 \%$ from 1995 to 2007 while TP for all other passenger transport types had a growth rate of less than $2 \%$ (Figure).

In 2007, the share of total TP was $74.8 \%\left(4,842 \times 10^{9}\right.$ pkm) by private transport (passenger car and powered two-wheeler), $8.8 \%\left(571 \times 10^{9} \mathrm{pkm}\right)$ by air, $8.3 \%$

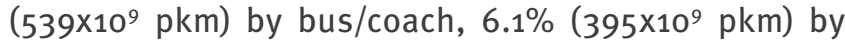
railway, $1.3 \%\left(85 \times 10^{9} \mathrm{pkm}\right)$ by tram/metro and $0.6 \%$ $\left(41 \times 10^{9} \mathrm{pkm}\right)$ by sea transport. Hence, all public ground transport (bus/coach, railway, tram/metro) generated a share of $15.7 \%$ of the total TP of $6,473 \times 10^{9} \mathrm{pkm}$ in the EU in 2007.

\section{German passenger transport}

In Germany public ground transport generated a share of $14.6 \%\left(161.5 \times 10^{9} \mathrm{pkm}\right)$ and air transport a share of $5.3 \%\left(59 \times 10^{9} \mathrm{pkm}\right)$ of the total German TP in 2007. In the same year the number of passengers (passenger volume) transported by public ground transport generated a share of $16.8 \%(11,387$ million passengers) and air transport a share of $0.2 \%$ (129 million passengers). Compared to 2004, railway and air transport generated a higher TP in 2007. However, the share of passengers travelling by air remained at a low level of $0.2 \%$ (see details in Table 1).

\section{FIGURE}

Passenger transport performance by mode of transport in passenger kilometres, EU-27, 1995-2007

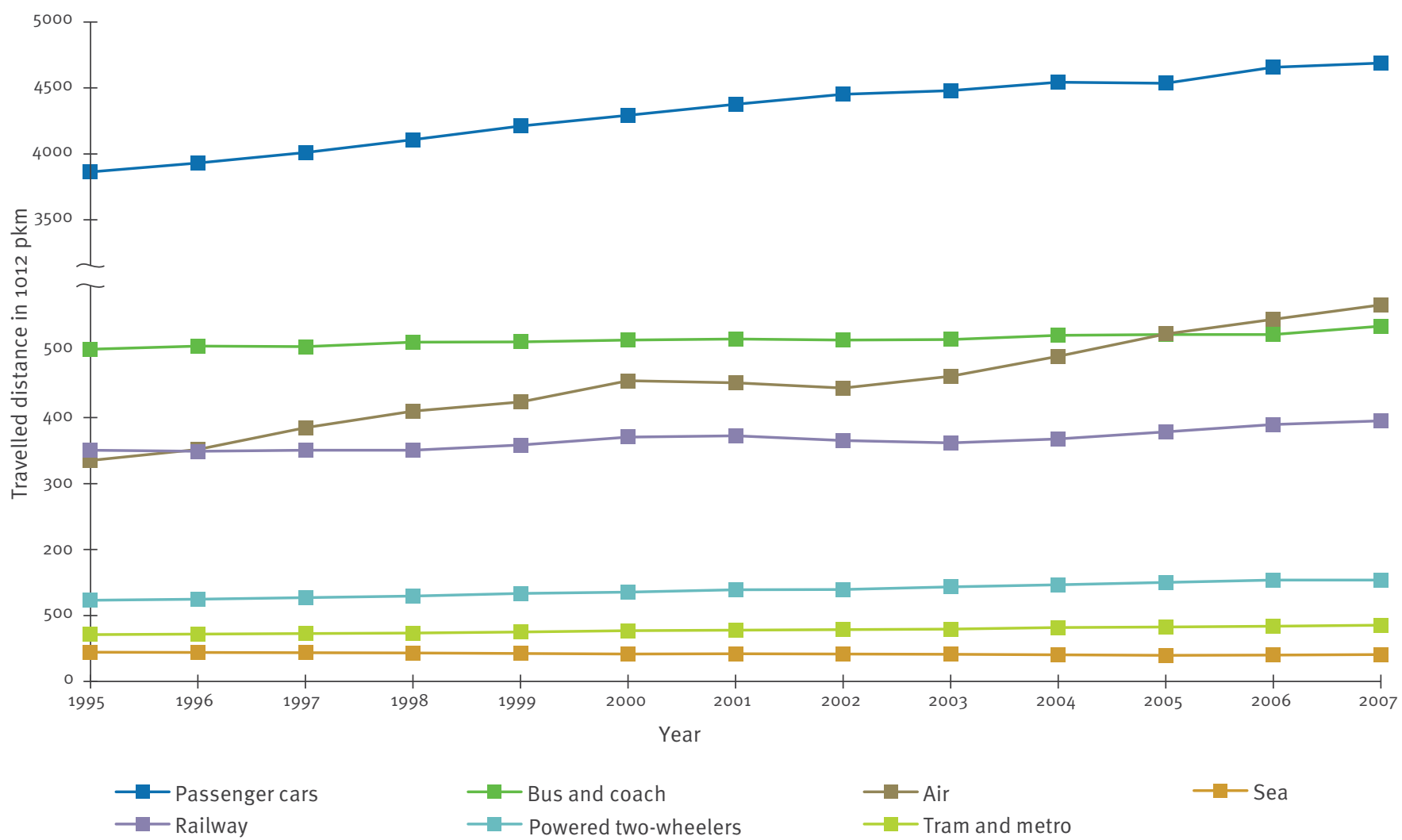


Passenger volume and passenger transport performance of different means of transport, Germany, 2004 and 2007

\begin{tabular}{|c|c|c|c|c|c|c|}
\hline & \multirow[b]{2}{*}{ Year } & \multirow{2}{*}{$\begin{array}{l}\text { Private transport } \\
\text { Passenger car and } \\
\text { Powered two-wheeler }\end{array}$} & \multicolumn{2}{|l|}{ Public ground transport } & \multirow[b]{2}{*}{ Air } & \multirow[b]{2}{*}{ Total } \\
\hline & & & $\begin{array}{l}\text { Public road transport } \\
\text { (Bus/coach and Tram/metro }\end{array}$ & Railway & & \\
\hline \multirow{2}{*}{$\begin{array}{l}\text { Passenger transport } \\
\text { performance } \\
\text { (in billion } \mathrm{pkm})^{\mathrm{a}}\end{array}$} & 2004 & $887(81.3 \%)$ & $83(7.6 \%)$ & $73(6.7 \%)$ & $48(4.4 \%)$ & 1,091 \\
\hline & 2007 & $885(80.1 \%)$ & $82(7.4 \%)$ & $79(7.2 \%)$ & $59(5.3 \%)$ & 1,106 \\
\hline \multirow{2}{*}{$\begin{array}{l}\text { Passenger } \\
\text { volume } \\
\text { (in million)a }\end{array}$} & 2004 & $57,275(83.6 \%)$ & $9,057(13.2 \%)$ & $2,091(3.1 \%)$ & $106(0.2 \%)$ & 68,529 \\
\hline & 2007 & $56,420(83.0 \%)$ & $9,146(13.5 \%)$ & $2,241(3.3 \%)$ & $129(0.2 \%)$ & 67,936 \\
\hline
\end{tabular}

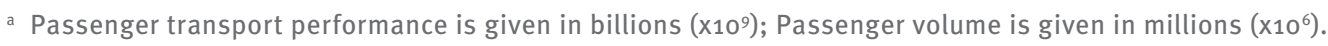

\section{TABLE 2}

Passenger transport performance, passenger volume and average travelled distance in short- and long-distance transport by bus/coach and railway, Germany, 2004 and 2007

\begin{tabular}{|c|c|c|c|c|c|c|c|c|}
\hline \multirow[b]{2}{*}{ Year } & \multicolumn{3}{|c|}{ Short-distance transport ${ }^{b}$} & \multicolumn{3}{|c|}{ Long-distance transportc } & \multirow[b]{2}{*}{$\begin{array}{c}\text { Total passenger } \\
\text { TPa }^{\text {a }} \\
\text { (in billion } \mathrm{pkm} \text { ) }\end{array}$} & \multirow[b]{2}{*}{$\begin{array}{c}\text { Total passenger } \\
\text { volume }^{a} \text { (in } \\
\text { million) }\end{array}$} \\
\hline & $\begin{array}{l}\text { Passenger } \\
\text { TPa (in } \\
\text { billion pkm) }\end{array}$ & $\begin{array}{l}\text { Passenger } \\
\text { volume }^{\mathrm{a}} \\
\text { (in million) }\end{array}$ & $\begin{array}{l}\text { Average } \\
\text { trip distance } \\
\text { (in } \mathrm{km})\end{array}$ & $\begin{array}{l}\text { Passenger } \\
\text { TP }^{a} \text { (in } \\
\text { billion pkm) }\end{array}$ & $\begin{array}{l}\text { Passenger } \\
\text { volume }^{\mathrm{a}} \\
\text { (in million) }\end{array}$ & $\begin{array}{l}\text { Average } \\
\text { trip distance } \\
\text { (in } \mathrm{km} \text { ) }\end{array}$ & & \\
\hline 2004 & $75(68.8 \%)$ & $7,213(98.4 \%)$ & 13.6 & $34(31.2 \%)$ & $121(1.6 \%)$ & 290.5 & 109 & 7,334 \\
\hline 2007 & $81(69.6 \%)$ & $7,374(98.4 \%)$ & 14.1 & $35(30.4 \%)$ & $121(1.6 \%)$ & 393.6 & 116 & 7,495 \\
\hline
\end{tabular}

TP: transport performance.

a TP is given in billions $\left(\mathrm{x}_{10^{9}}\right)$; Passenger volume is given in millions $\left(\mathrm{x}_{10} 0^{6}\right)$.

b Short-distance transport: travel distance $<50 \mathrm{~km}$.

c Long-distance transport: travel distance $>50 \mathrm{~km}$ or transport in predefined conveyances such as high speed trains.

About two thirds (69.6\%) of the TP and $98 \%$ of passenger volume in ground transport were generated by short-distance travel in Germany in 2007 (Table 2). In comparison with the data from 2004, the average trip distance for long-distance transport by bus/coach and railway increased by $26 \%$.

\section{Environmental conditions in} ground transport conveyances

The scientific literature search resulted in around 1,600 hits. After screening of title and abstract, 11 potentially relevant publications were identified and the full text article read. Finally, six articles addressing environmental conditions and possible airborne infectious disease transmission in public ground transport in busses and trains were selected [20-25]. Four of the six articles were published in 2010 or later, the other two in 2000 and 2007. Five identified articles described results of Computational Fluid Dynamics (CFD) models simulating the risk of airborne infection in public ground transport by investigating the microenvironmental conditions or characteristics of the dispersion of expiratory droplets and droplet nuclei in public busses or trains. Two articles assessed the pathogen-specific transmission risk for influenza $[22,25]$, one article the risk for Mycobacterium tuberculosis [20]. Another study validated the results of its CFD model by monitoring the quality of the indoor environment on the Harvard University shuttle bus [21].

According to the models, air distribution method, ventilation rate, exposure time and seat arrangement/seating position (in terms of proximity) affected the risk of transmission of airborne infectious diseases on buses and trains $[22,25]$. Air circulation mode with displacement ventilation method or high efficiency filtration was found to reduce the infection risk [22]. The study published by Furuya in 2007 assessed the influence of environmental parameters by varying the duration of exposure and the number of passengers [25]. A mathematical model based on the Wells-Riley model was used including the reproduction number $R_{A}$ for influenza infection on a train. According to the results the exposure time was found to increase the risk linearly. 
In addition, the number of passengers also increased the risk, whereas doubling the rate of ventilation limited the transmission risk by reducing the estimated reproduction number for influenza in the vehicle [25].

The sixth article describes two surveys of commercial transportation including aircrafts, interstate busses, short-distance commuter trains and subways, which were conducted in 1994 and 1996 [24]. Beside other environmental measurements such as carbon dioxide $\left(\mathrm{CO}_{2}\right)$, surface dust was collected using handheld vacuum cleaners, sifted, and fine particles analysed for bacteria. Although the total concentration (in colonyforming unit $/ \mathrm{m}^{3}$ ) of airborne bacteria was not statistically different across the various travel modes (except for samples taken inside the aircraft cabin during deboarding); the highest geometric mean concentration of bacteria in ground travel was found in subways, followed by trains. However, the authors point out that identification of bacteria and detection of viruses important for evaluating the respiratory infectious risk were not performed [24].

Of six contacted transport organisations and companies, one internationally operating transport organisation agreed to share information on the technical properties of air conditioning systems in public ground conveyances. According to this information, HEPAfilters are not used at all in ground conveyances. In addition, due to the technical diversity within the vehicle fleet, technical equipment such as ventilation systems and seating arrangements in ground conveyances may differ significantly even within one transport company. Based on information of one company high-speed trains used for long-distance travel in most EU-countries often use coarse dust filters (G4-filter/EU 4-filter) [26] to remove particles above $10 \mu \mathrm{m}$.

The REACT experts concluded that environmental parameters do have an effect in the risk of transmission of infectious disease from one passenger to another in public ground transport. While the duration of exposure and proximity to other passengers are seen as important parameters in assessing the risk of disease transmission, little is known about the influence of technical parameters such as ventilation systems in ground conveyances on transmission. Even though simulation models demonstrate the potential influence of different environmental conditions on the risk of airborne disease transmission in public ground transport, evidence from experimental and microbial investigations in real events is still insufficient. Furthermore the experts agreed that access to information on environmental conditions and the wide range of technical features is limited. In addition, the assessment of such technical information with regard to risk of infectious disease transmission in public transport is challenging for health professionals.
Indications for CT in public ground transport The REACT experts agreed that consideration for CT in ground transport should follow the same principles as in air travel. Overall, the judgement was that even though scientific evidence is lacking, the chance for transmission of infectious disease from one passenger to another in public ground transport might be the same as on airplanes. It was acknowledged that in public ground transport there is often no documentation in place to identify passengers with the exact seating position which makes it impossible to trace passengers individually. Furthermore, public ground transport often works without passenger attendants, making it more difficult to implement the system of passenger locator cards.

During two expert meetings and two round table discussions the REACT experts agreed to exclude foodborne and vector-borne pathogens as indications for CT. They concluded that CT should generally be considered in situations with the following diseases: pulmonary tuberculosis, meningococcal disease, viral hemorrhagic fever, Lassa fever and measles [14]. Important factors influencing their decision were their personal experience concerning the feasibility of CT in various settings, the severity of an infectious disease, its infectiousness, and the possibility of providing an effective therapy after tracing contact persons.

\section{Minimal dataset for contact tracing}

The experts of the REACT project suggested that, in order to work towards integrated surveillance systems, a minimal data set for CT in public ground transport should require similar data as recommended for $\mathrm{CT}$ in air transport. It was agreed that the items requested in the locator form in its updated version cover all and even more than the essential information necessary to potentially initiate $\mathrm{CT}$.

\section{Discussion}

Public ground transport in the EU covers more travel than air transport. In Germany TP is nearly threefold, and passenger volume nearly 90 -fold higher for ground transport as for air transport. Although the data do not allow the computation of person travel time, these figures indicate the importance of exposure during travel in public ground transport compared to air travel. However, we cannot exclude that short-time exposure may not be important in the transmission of infectious diseases in public ground transport. Furthermore there is evidence that cumulative exposure in repetitive short trips can lead to disease transmission, e.g. reports on cases of TB transmission on school busses [27-29].

Duration of exposure, however, is only one suspected influence on the risk of person to person transmission [30]. For pathogens transmitted by droplets the proximity and the interaction between two passengers plays a role [30-33] and may not differ between ground and air travel as long as individual seating is available for 
all passengers. For airborne pathogens the type of air ventilation system may have a relevant impact on how long infectious particles will persist in the air [23,3436]. As documented for tuberculosis, droplet nuclei particles may be transported through ventilation systems [37] and remain suspended and viable in the air over a period of time [38-41].

Some air filter systems with a cut-off of $0.3 \mu \mathrm{m}$ are capable of removing airborne bacteria such as Mycobacterium tuberculosis. These HEPA filters are used in most aircrafts on flights within the EU $[42,43]$ but not in busses/coaches, trains or tram/metro. Some modern high-speed trains are reported to use coarse dust filters which would not limit the spread of certain airborne pathogens, such as Mycobacterium tuberculosis. Ground transport therefore provides a more favourable environment for airborne transmission.

Given that the frequency of potential exposure and the environmental conditions are comparable, the reason why $\mathrm{CT}$ is less regularly conducted in public ground transport is likely to be the result of logistic challenges rather than lower risk for transmission. Indeed, even when passengers have assigned seating positions, ground transport companies have more difficulties in making passenger contact information available for CT as no passenger-related data is stored.

However, various airlines have abandoned passengerspecific seat assignments and thus cannot provide seat-specific passenger data at all. This lead to the concept of passenger locator forms, filled in by the passengers themselves [12]. These forms have been used in situations where a potential disease transmission has already been identified during the flight, and passenger attendants were able to hand the passenger locator forms as they leave the plane [12]. In ground transport this approach seems not feasible for practical reasons, e.g. because of higher flexibility and less documentation regarding itinerary and seating.

In comparison to the 2009 passenger locator form [12], Annex III of the amended Decision 2000/57/EC also contains questions on nationality, ID type, ID number, and issuing authority [2]. We believe these data are unnecessary and possibly problematic from the point of view of data confidentiality. At least in Germany the legal framework does not authorise health departments to use passports for patient identification, nor does it allow involving police authorities to use these data to identify or find a contact person. While legislation in other countries may not be so restrictive, it seems unnecessary to request ID numbers in such a context. Whatever strategy is chosen to identify and locate exposed passengers, the information collected in the WHO passenger locator form appears sufficient to the REACT experts with respect to possibilities to contact passengers, and the additional suggestions in Annex III of the amended Decision 2000/57/EC [2,12] may cause more legal concerns than additional benefit.
All relevant issues considered, individual CT of passengers in ground transport seems only feasible in cases where contacts are known by other circumstances, e.g. a school outing by bus or train [44]. One way of identifying possible contacts of an ill passenger is to involve the mass media. However, a public call for contacts may cause unnecessary anxiety among passengers who are not at risk and might at the same time miss the attention of co-travellers who are at risk. Nevertheless, in case of exposure to a very severe disease, this approach may be considered.

Modern Internet-based technologies offer an option of posting announcements related to possible transmission of infectious diseases during travel. Coded secure access to the passengers who travelled on a particular occasion might stimulate a better response as many data confidentiality concerns would be resolved. The acceptance of these alternative systems can be further investigated with participation of relevant stakeholders and in view of the data presented here.

The presented EU data refer to figures published in 2009. These were the most recent data we were able to use. Due to the delay in data collection, the data always seem to be outdated by two years. However, the trends described seem to be stable over time.

The transport statistics presented here give only a limited view on the likelihood of infectious disease transmission on board of public transport conveyances partly because of the territorial principle of data collection. More importantly, the duration of the trip as a commonly described proxy for risk of infection [4,4549] is not measured. Furthermore, data on passenger volume for the different means of transport are not available for the 27 EU Member States.

Within the scope of this study, we could analyse in detail the data from one EU country only, Germany. However, the transport data is well comparable to the most populous EU countries (France, Italy and the United Kingdom) and the conclusions might also be applicable for the other EU countries.

Even taking into account the limitations of our assessment we showed that the risk for infectious disease transmission is comparable between ground and air transport. Logistical difficulties in implementing CT in ground transport raise the question of whether more efforts are needed to reinforce ground transport CT or rather whether the established way of conducting $\mathrm{CT}$ in air transport should be reviewed. We therefore suggest that the indications for CT should be revisited in general terms. 


\section{Acknowledgments}

We thank the following experts and colleagues for sharing their knowledge and judgement for this work: Philip Monk (HPA, Local and Regional Services, UK), Corien Swaan (RIVM, Netherlands), Udo Goetsch (Frankfurt Department of Health, Germany), René Gottschalk (Frankfurt Department of Health, Germany), Daniel Menucci (WHO-Office IHR, France) and Lindsey Barr (International Association of Public Transport, Belgium).

This publication arises from the project REACT which has received funding from the EU, in the framework of the Public Health Programme (funding number 2007211).

\section{References}

1. Eurostat, European Commission. Panorama of Transport. 6th ed. Luxembourg: Office for Official Publications of the European Communities, 2009. ISBN 978-92-79-11119-8. Available from: http://epp.eurostat.ec.europa.eu/cache/ITY OFFPUB/KS-DA-09-001/EN/KS-DA-09-001-EN.PDF

2. European Commission. Commission Decision of 10 July 2009 amending Decision 2000/57/EC on the early warning and response system for the prevention and control of communicable diseases under Decision No 2119/98/EC of the European Parliament and of the Council. Offical Journal of the European Communities. 2009; L 181:57-60. Available from: http://eur-lex.europa.eu/LexUriServ/LexUriServ.do?uri=0J:L:2 009:181:0057:0060:EN:PDF

3. Martinez L, Thomas K, Figueroa J. Guidance from WHO on the prevention and control of TB during air travel. Travel Med Infect Dis. 2010;8(2):84-9.

4. World Health Organization (WHO). Tuberculosis and ai travel: guidelines for prevention and control. 3rd ed. Report No. WHO/HTM/TB/2008.399. Geneva: WHO; 2008. Available from: http://www.who.int/tb/publications/2008/WHO_HTM TB_2008.399_eng.pdf

5. Centers for Disease Control and Prevention (CDC). Exposure to patients with meningococcal disease on aircrafts United States, 1999-2001. MMWR Morb Mortal Wkly Rep. 2001;50(23):485-9.

6. Public Health Agency of Canada. Update: Guidelines for the prevention and control of meningococcal disease. Canada Communicable Disease Report (CCDR). 2006;32(22). Available from: http://www.phac-aspc.gc.ca/publicat/ccdrrmtc/o6vol32/dr3222c-eng.php

7. Public Health Agency of Canada. Guidelines for the prevention and control of meningococcal disease. Canada Communicable Disease Report (CCDR). 2005;31S1. Available from: http://www. phac-aspc.gc.ca/publicat/ccdr-rmtc/05vol31/31s1/index-eng. php

8. WHO recommended measures for persons undertaking international travel from areas affected by severe acute respiratory syndrome (SARS). Wkly Epidemiol Rec. 2003;78(14):97-9.

9. Centers for Disease Control and Prevention (CDC). Guidance about SARS for Airline Flight Crews, Cargo and Cleaning Personnel, and Personnel Interacting with Arriving Passengers. Atlanta: CDC; 23 Apr 2004. Available from: http://www.cdc. gov/sars/travel/airpersonnel.html

10. Public Health Agency of Canada. SARS and air travel: interim guidelines for prevention and control. Ottawa: Public Health Agency of Canada; 8 May 2003. Available from: http://www. phac-aspc.gc.ca/sars-sras/ic-ci/sars-mangmtpax-eng.php

11. International Air Transport Association (IATA). Suspected communicable diseases - general guidelines for cabin crew. Geneva: IATA; Oct 2011. Available from: http://www.iata.org/ whatwedo/safety security/safety/health/Documents/healthguidelines-cabin-crew-2011.pdf

12. World Health Organization (WHO), International Civil Aviation Organization (ICAO), International Air Transport Association (IATA). WHO technical advice for case management of Influenza $\mathrm{A}\left(\mathrm{H}_{1} \mathrm{~N}_{1}\right)$ in air transport. Geneva: WHO: 13 May 2009. Available from: http://www.who.int/ihr/travel/A\%28H1N1\%29_air transport_guidance.pdf

13. Aerospace Medical Association Task Force. Emerging infectious diseases including severe acute respiratory syndrome (SARS) guidelines for commercial air travel and air medical transport. Aviat Space Environ Med. 2004;75(1):85-6.

14. Robert Koch Institute (RKI). The REACT project. Response to Emerging infectious disease: Assessment and development of
Core capacities and Tools. Berlin: RKI; 16 Feb 2011. Available from: www.rki.de/react

15. European Commission. EU energy and transport in figures. Statistical pocketbook 2009. Luxembourg: European Commission. 2009. ISBN 978-92-79-10728-3 Available from: http://ec.europa.eu/transport/publications/statistics/ doc/2009_energy_transport_figures.pdf

16. Radke S. Verkehr in Zahlen 2008/2009. [Transport in figures 2008/2009]. Berlin: Bundesministerium für Verkehr, Bau- und Stadtentwicklung; 2009. German.

17. Statistisches Bundesamt (Destatis). Statistisches Jahrbuch 2008 für die Bundesrepublik Deutschland. [Statistical Yearbook 2008 for the Federal Republic of Germany]. Wiesbaden: Statistisches Bundesamt; 2008. German. Available from: http://www.bpb.de/files/33F300.pdf

18. Reichel B. Öffentlicher Personenverkehr mit Bussen und Bahnen 2006. [Public passenger transport on buses and trains]. Wiesbaden: Statistisches Bundesamt; Sep 2008. German. Available from: https://www.destatis.de/DE/ Publikationen/WirtschaftStatistik/Verkehr/BusseBahnen2006. pdf?_blob=publicationFile

19. Statistisches Bundesamt (Destatis). Verkehr im Überblick 2007. Wiesbaden: Statistisches Bundesamt; 10 Sep 2008. German. Available from: https://www.destatis.de/DE/ Publikationen/Thematisch/TransportVerkehr/Querschnitt/ VerkehrUeberblick2080120077004.pdf?_blob=publicationFile

20. Chen SC, Liao CM, Li SS, You SH. A probabilistic transmission model to assess infection risk from Mycobacterium tuberculosis in commercial passenger trains. Risk Anal. 2011;31(6):930-9.

21. Zhu S, Demokritou P, Spengler J. Experimental and numerical investigation of micro-environmental conditions in public transportation buses. Building and Environment. 2010;45(10):2077-88.

22. Zhu S, Srebric J, Spengler JD, Demokritou P. An advanced numerical model for the assessment of airborne transmission of influenza in bus microenvironments. Building and Environment. 2012;47:67-75.

23. Zhang L, Li Y. Dispersion of coughed droplets in a fullyoccupied high-speed rail cabin. Building and Environment. 2012;47:58-66.

24. Dumyahn TS, Spengler JD, Burge HA, Muilenburg M. Comparison of the environments of transportation vehicles: Results of two surveys. In: Nagda NL, editor. Air Quality and Comfort in Airliner Cabins, ASTM STP 1393. West Conshohocken: American Society for Testing and Materials; 2000. p. 3-23.

25. Furuya $H$. Risk of transmission of airborne infection during train commute based on mathematical model. Environ Health Prev Med. 2007;12(2):78-83.

26. DIN EN 779: Partikel-Luftfilter für die allgemeine Raumlufttechnik - Bestimmung der Filterleistung; Deutsche Fassung prEN 779:2009. [Particulate air filters for general ventilation - determination of the filtration performance; German version prEN 779:2009]. Berlin: Deutsches Institut für Normung e. V. (DIN); 7 Dec 2009. German. Available from: http://www.baunormenlexikon.de/Normen/DIN/DIN\%20 EN\%20779/38540632-da56-424a-8335-935cc7557a8f

27. The LODI tuberculosis working group. A school- and community-based outbreak of Mycobacterium tuberculosis in Northern Italy, 1992-3. Epidemiol Infect .1994;113(1):83-93.

28. Curtis AB, Ridzon R, Vogel R, Mcdonough S, Hargreaves J, Ferry , et al. Extensive transmission of Mycobacterium tuberculosis from a child. New Engl J Med. 1999;341(20):1491-5.

29. Neira-Munoz E, Smith J, Cockcroft P, Basher D, Abubakar I. Extensive transmission of Mycobacterium tuberculosis among children on a school bus. Pediatr Infect Dis J. 2008;27(9):835-7.

30. Edelson PJ, Phypers M. TB transmission on public transportation: a review of published studies and recommendations for contact tracing. Travel Med Infect Dis. 2011;9(1):27-31.

31. Beggs CB, Noakes CJ, Sleigh PA, Fletcher LA, Siddiqi K. The transmission of tuberculosis in confined spaces: an analytical review of alternative epidemiological models. Int J Tuberc Lung Dis. 2003;7(11):1015-26.

32. Beard FH, McAnulty JM, Tapsall JW, Zaia AM. Probable transmission of meningococcal disease on a school bus. Med ] Aust. 2006;184(2):90.

33. The Lodi Tuberculosis Working Group. A school- and community-based outbreak of Mycobacterium tuberculosis in Northern Italy, 1992-3. Epidemiol Infect. 1994;113(1):83-93.

34. Wan MP, Chao CYH. Transport characteristics of expiratory droplets and droplet nuclei in indoor environments with different ventilation airflow patterns. J Biomech Eng. 2007;129(3):341-53. 
35. Gupta JK, Lin CH, Chen Q. Transport of expiratory droplets in an aircraft cabin. Indoor Air. 2010;21(1):3-11.

36. Morawska L. Droplet fate in indoor environments, or can we prevent the spread of infection? Indoor Air. 2006;16(5):333-47.

37. Li Y, Leung GM, Tang JW, Yang X, Chao CY, Lin JZ, et al. Role of ventilation in airborne transmission of infectious agents in the built environment - a multidisciplinary systematic review. Indoor Air. 2007;17(1):2-18.

38. Riley RL. Airborne infection. Am J Med. 1974;57(3):466-75.

39. Nardell EA. Catching droplet nuclei: toward a better understanding of tuberculosis transmission. Am J Respir Crit Care Med. 2004;169(5):553-4.

40. Fennelly KP, Martyny JW, Fulton KE, Orme IM, Cave DM, Heifets LB. Cough-generated aerosols of Mycobacterium tuberculosis: a new method to study infectiousness. Am J Respir Crit Care Med. 2004;169(5):604-9.

41. Wells WF, Stone WR. On air-borne infection. Study III. Viability of droplet nuclei infection. Am J Hyg. 1934;20:619-27.

42. Hocking MB. Passenger aircraft cabin air quality: trends, effects, societal costs, proposals. Chemosphere 2000;41(4):603-15.

43. European Centre for Disease Prevention and Control (ECDC). Risk assessment guidelines for infectious diseases transmitted on aircraft. ECDC Technical report. Stockholm: ECDC; Jun 2009. Available from: http://www.ecdc.europa.eu/en/publications/ Publications/0906_TER_Risk_Assessment_Guidelines_for_ Infectious_Diseases_Transmitted_on_Aircraft.pdf

44. Zuschneid I, Witschi A, Quaback L, Hellenbrand W, Kleinkauf $\mathrm{N}$, Koch D, et al. Invasive meningococcal disease with fatal outcome in a Swiss student visiting Berlin. Euro Surveill 2008;13(45): pii=19031. Available from: http://www. eurosurveillance.org/ViewArticle.aspx?Articleld=19031

45. Kenyon TA, Valway SE, Ihle WW, Onorato IM, Castro KG. Transmission of multidrug-resistant Mycobacterium tuberculosis during a long airplane flight. N Engl J Med. 1996;334(15):933-8.

46. Abubakar I. Tuberculosis and air travel: a systematic review and analysis of policy. Lancet Infect Dis. 2010;10(3):176-83.

47. Centers for Disease Control and Prevention (CDC). Exposure of passengers and flight crew to Mycobacterium tuberculosis on commercial aircraft, 1992-1995. MMWR Morb Mortal Wkly Rep. 1995;44(8):137-40.

48. Driver CR, Valway SE, Morgan WM, Onorato IM, Castro KG. Transmission of Mycobacterium tuberculosis associated with air travel. JAMA. 1994;272(13):1031-5.

49. Miller MA, Valway S, Onorato IM. Tuberculosis risk after exposure on airplanes. Tuber Lung Dis. 1996;77(5):414-9. . 